\title{
OPEN Author Correction: Climate change impact on flood and extreme precipitation increases with water availability
}

\author{
Hossein Tabari \\ Correction to: Scientific Reports https://doi.org/10.1038/s41598-020-70816-2, published online 13 August 2020 \\ The original version of this Article contained a typographical error in the Abstract. \\ "Results show an intensification of extreme precipitation and flood events over all climate regions which increases \\ as water availability increases from wet to dry regions." \\ now reads:
}

"Results show an intensification of extreme precipitation and flood events over all climate regions which increases as water availability increases from dry to wet regions."

This error has now been corrected in the PDF and HTML versions of the Article.

\begin{abstract}
(c) (1) Open Access This article is licensed under a Creative Commons Attribution 4.0 International License, which permits use, sharing, adaptation, distribution and reproduction in any medium or format, as long as you give appropriate credit to the original author(s) and the source, provide a link to the Creative Commons licence, and indicate if changes were made. The images or other third party material in this article are included in the article's Creative Commons licence, unless indicated otherwise in a credit line to the material. If material is not included in the article's Creative Commons licence and your intended use is not permitted by statutory regulation or exceeds the permitted use, you will need to obtain permission directly from the copyright holder. To view a copy of this licence, visit http://creativecommons.org/licenses/by/4.0/.
\end{abstract}

(C) The Author(s) 2020 